ISSN 0258-7122

Bangladesh J. Agril. Res. 34(4) : 661-672, December 2009

\title{
EVALUATION OF SPAD AND LCC BASED NITROGEN MANAGEMENT IN RICE (Oryza sativa L.)
}

\author{
M.Sh. ISLAM ${ }^{1}$, M. S. U. BHUIYA ${ }^{2}$, S. RAHMAN ${ }^{3}$ \\ AND M. M. HUSSAIN ${ }^{4}$
}

\begin{abstract}
A study was conducted during Boro and T. Aman seasons of 2002 at Bangladesh Rice Research Institute (BRRI), Gazipur to see the relationship of SPAD (Soil plant analysis development) reading with chlorophyll and $\mathrm{N}$ contents of leaves and to determine the critical LCC value for rice crops. Hybrid varieties Sonarbangla-1 and BRRI hybrid dhan0l were used for both rice crops and BRRI dhan29 and BRRI dhan31 were used as checks for Boro and T. Aman crops, respectively. Sonarbangla-1, BRRI hybrid dhan0l and BRRI dhan29 had similar leaf chlorophyll contents in Boro season. The maximum chlorophyll content (1.6-1.8 mg/g leaf) was observed at 39-42 soil plant analysis development (SPAD) value. In T. Aman season, the inbred BRRI dhan3l showed lower amount of chlorophyll (1.2-1.4 mg/g leaf) at 39-42 SPAD value compared to the hybrids Sonarbangla-1 and BRRI hybrid dhan 0l. Seasonal variation in chlorophyll content between Sonarbangla-1 and BRRI hybrid dhan0l was not large. Relationship between SPAD value and chlorophyll content was very close $\left(\mathrm{R}^{2}=>0.8\right)$ at panicle initiation and flower initiation stages for all the varieties. Similar relationship was also observed in case of SPAD value and nitrogen content in leaves. The results indicated that the rice leaves showing higher SPAD readings (>35) had higher chlorophyll and nitrogen contents. The adjusted critical LCC values were 3.0 for Boro and 3.5 for T. Aman seasons for all rice varieties.
\end{abstract}

Key Words: Chlorophyll, nitrogen.

\section{Introduction}

Nitrogen is the most deficient nutrient element in Bangladesh soils. An adequate supply of nitrogen can increase as much as $60 \%$ rice yield (Mikkelsen et al., 1995). Top dressing of $\mathrm{N}$ is needed when the crop has a great need for $\mathrm{N}$ and when the rate of $\mathrm{N}$ uptake is large (Dobermann and Fairhurst, 2000). Cropdemand based $\mathrm{N}$ application is one of the important options to reduce $\mathrm{N}$ loss and to increase $\mathrm{N}$ use efficiency of a crop. Chlorophyll meter (SPAD) or leaf colour chart (LCC) can be used for adjustment of fertilizer $\mathrm{N}$ application based on actual plant N status (Balasubramanian et al., 1999). Need based N application would result in greater agronomic efficiency of $\mathrm{N}$ fertilizer than the commonly practiced

\footnotetext{
${ }^{1}$ Seinor Scientific Officer (Agronomy), BRRI R/S Barisal, ${ }^{2}$ Professor, Dept. of Agronomy, BAU, Mymensingh, ${ }^{3}$ Scientific Officer, Plant Physiology Division, BRRI, Joydebpur, Gazipur 1701 and ${ }^{4}$ Chief Scientific Officer \& Head, ARD, BRRI, Joydebpur, Gazipur 1701, Bangladesh.
} 
method (Hussain et al., 2000). Au (2005) reported that the requirement of $\mathrm{N}$ fertilizer based on SPAD reading was found 15 and $40 \mathrm{~kg}$ N/ha lower compared to conventional $\mathrm{N}$ management during wet and dry seasons, respectively. The SPAD value-based $\mathrm{N}$ application can increase grain yield and $\mathrm{N}$ use efficiency of both hybrid and inbred varieties and hybrid can give an advantage of $6.5 \%$ due to heterosis over the inbred varieties (Peng et al., 1998). The SPAD meter- based $\mathrm{N}$ management appeared to be more efficient and would save 20-30 $\mathrm{kg} \mathrm{N} / \mathrm{ha}$ than the conventional $\mathrm{N}$ management practices to produce similar grain yield (Miah and Abmed, 2002). Tropical hybrid rice generally has thinner leaves and a slightly lower leaf $\mathrm{N}$ concentration than inbreds. So, the SPAD threshold for tropical hybrids will be slightly less than that of inbred cultivars. A SPAD threshold value of 35 is equivalent to $1.4-1.5 \mathrm{~g} \mathrm{~N} / \mathrm{m}^{2}$ leaf area in semi-dwarf indica varieties (Peng et al., 1996).

However, in Bangladesh, most research works have so far been focused mostly on the rate and timing of $\mathrm{N}$ application without considering the initial soil nitrogen and crop demand. So, a study is needed on crop-demand based $\mathrm{N}$ management through assessing the soil plant analysis development (SPAD) value and to correlate SPAD values with leaf colour chart (LCC) reading for specific variety and season. The present study was, therefore, undertaken to determine relationship between SPAD reading and $\mathrm{N}$ and chlorophyll content in rice leaves, iv) determine critical threshold LCC value of hybrid and inbred rice varieties.

\section{Materials and Method}

\section{Site and soil}

Field experiments were conducted at the experimental farm of the Bangladesh Rice Research Institute (BRRI), Gazipur during Boro and T. Aman seasons 2002. The soil was silty clay loam and slightly acidic (pH 6.2) with total $\mathrm{N} 0.11 \%$ and organic matter (OM) 2.05\%.

\section{Treatments}

The experiment was conducted in a randomized complete block design (RCBD) with 3 replications. It was a 2 factor experiments, one factor was $\mathrm{N}$ management and the other factor was rice variety. There were $10 \mathrm{~N}$ management treatments:

$\mathrm{N}_{0}=$ Control (No)

$\mathrm{N}_{1}=40 \mathrm{~kg} N /$ ha in 2 equal splits at early tillering (ET) and panicle initiation (P1) stage

$\mathrm{N}_{2}=80 \mathrm{~kg} \mathrm{~N} / \mathrm{ha}$ in 2 equal splits at ET and P1 stage

$\mathrm{N}_{3}=120 \mathrm{~kg} \mathrm{~N} / \mathrm{ha}$ in 3 equal splits at basal, mid-tillering (MT) and P1 stage

$\mathrm{N}_{4}=120 \mathrm{~kg} \mathrm{~N} / \mathrm{ha}$ in 3 equal splits at ET, MT and P1 stage 
$\mathrm{N}_{5}=160 \mathrm{~kg} \mathrm{~N} / \mathrm{ha}$ in 4 equal splits at basal, MT, P1 and heading stage

$\mathrm{N}_{6}=160 \mathrm{~kg} \mathrm{~N} / \mathrm{ha}$ in 4 equal splits at ET, MT, P1 and heading stage

$\mathrm{N}_{7}=30 \mathrm{~kg} \mathrm{~N} / \mathrm{ha}$ at $\leq 35$ Soil Plant Analysis Development (SPAD) value with basal $30 \mathrm{~kg} \mathrm{~N} / \mathrm{ha}$

$\mathrm{N}_{8}=30 \mathrm{~kg} \mathrm{~N} / \mathrm{ha}$ at $\leq 35 \mathrm{SPAD}$ value (from $20 \mathrm{DAT}$ to heading) without basal $\mathrm{N}$

$\mathrm{N}_{9}=80 \mathrm{~kg} \mathrm{~N} / \mathrm{ha}$ as USG deep placement [3 granules (0.9 g size) in-between alternate 4 hills]

Concerning varieties, hybrid Sonarbangla-1 and BRRI hybrid dhan0l were common and inbred varieties BRRI dhan 29 and BRRI dhan31 were used in Boro and T. Aman seasons, respectively.

\section{Cultural operations}

The experiment was laid out in a randomized complete block design (RCBD) with three replications, the unit plot size being $4 \mathrm{~m} \mathrm{x} 4 \mathrm{~m}$. Transplanting was done with 40-day and 25-day old seedlings in Boro and T. Aman season, respectively. One healthy seedling (for both hybrid and inbred varieties) was transplanted in a spacing of $20 \times 20 \mathrm{~cm}$. Gap filling for dead seedling was done within 10 days after transplanting (DAT). Fertilizers were applied @ 26-41-10-5 $\mathrm{kg} / \mathrm{ha} \mathrm{P}, \mathrm{K}, \mathrm{S}$ and Zn (blanket dose) as basal before transplanting. Cultural practices for weed and pest management were done as and when necessary.

\section{SPAD reading}

The SPAD meter is a simple portable diagnostic tool used for monitoring crop $\mathrm{N}$ status in situ in the field. To achieve the maximum yield target, the $\mathrm{N}$ concentration of the upper most fully expanded leaf must be maintained at or above $1.4 \mathrm{~g} \mathrm{~N} / \mathrm{m}^{2}$ (leaf area basis). Leaf $\mathrm{N}$ status at this critical level gives a SPAD value of 35 regardless of genotypes (Dobermann and Fairhurst, 2000). The SPAD reading was taken by a chlorophyll meter (SPAD-502, Minolta Camera Co., Japan). The LCC is a plastic scale with a green colour gradient from 1 to 6 (very light green to dark green) by which greenness of rice leaves can be measured. Data for SPAD and LCC values were collected from the same leaves from 20 DAT at 7-day intervals up to 50\% flower initiation. The SPAD and LCC readings were taken from the middle portion of the fully expanded youngest leaves from 5 randomly selected hills. When the SPAD reading came down to critical value 35, corresponding LCC value was considered as critical LCC value of that variety.

\section{Determination of $\mathbf{N}$ and chlorophyll content in rice leaves}

To establish the relationship between SPAD value and $\mathrm{N}$ content and chlorophyll content in the leaves, the leaves were harvested just after taking the SPAD 
readings. This sampling was done at panicle initiation, flowering and hard dough stages. For chlorophyll estimation, harvested leaf samples were taken in a bowl with water with marked SPAD values and numbering. Leaf samples were then immediately taken to the laboratory for subsequent analysis. Leaf samples were segmented, $20 \mathrm{mg}$ sample was weighed and poured into small pots containing 20 $\mathrm{ml} 80 \%$ acetone solution and placed in dark for 48 hours. Chlorophyll was measured from the leaf extract by a spectrophotometer following Yoshida et al. (1976) as:

Total chlorophyll $(\mathrm{mg} / \mathrm{g})=\frac{\mathrm{D} 652 \mathrm{~nm} \times 1000-\mathrm{mg} / \mathrm{liter}}{34.5}$

where, D652 $(\mathrm{nm})=$ Wave length adjusted during spectrophotometer readings when chlorophyll a and b intersect; 34.5 is the specific absorption coefficient for both pigments at this wave length.

The rest of the leaves were kept in marked envelopes (with SPAD value) and dried in oven at $70^{\circ} \mathrm{C}$ for 72 hours for subsequent estimation of leaf nitrogen content. Nitrogen concentration in leaves was determined from leaf samples at different growth stages following Kjeldahl wet oxidation method (Page et al., 1982).

Table 1. Critical LCC values of different varieties of rice.

\begin{tabular}{l|l|l}
\hline \multicolumn{1}{c}{ Variety } & Critical SPAD value & Critical LCC value \\
\hline T.aman rice & \multicolumn{2}{c}{$3.4 \approx 3.5$} \\
Sonarbangla-l & 35 & $3.4 \approx 3.5$ \\
BRRI hybrid dhan0l & 35 & $3.4 \approx 3.5$ \\
BRRIdhan3l & 35 & \\
\hline Boro_rice & 3.0 \\
\hline Sonarbangla-l & 35 & $3.1 \approx 3.0$ \\
BRRI hybrid dhan0l & 35 & $3.1 \approx 3.0$ \\
BRRIdhan3l & 35 &
\end{tabular}

\section{Results and Discussion}

\section{Relationship between SPAD value and chlorophyll content}

Figure la and $\mathrm{lb}$ show strong linear relationship between SPAD value and chlorophyll content $\left(\mathrm{R}^{2}=0.9\right)$ at different growth stages. For Boro rice, all varieties had similar leaf chlorophyll content (Figure 1a). In T. Aman, BRRI dhan31 showed lower amount of chlorophyll (1.2-1.4 mg/g) at 39-42 SPAD value compared to the others (Fig. 1b). BRRI dhan29 had about 1.6-1.8 mg chlorophyll/g leaf within the same range of SPAD values in Boro season. Chlorophyll content in rice leaves mostly varied with varieties and seasons. Sonarbangla-1 and BRRI hybrid dhan0l showed similar amount of chlorophyll 
content in leaves for both seasons. Boro variety BRRI dhan29 contained higher amount of chlorophyll compared to T. aman variety BRRI dhan3l.

Table 2.1. SPAD reading and $N$ content in leaves of BRRI hybrid dhan0l under different nitrogen management, Boro 2002.

\begin{tabular}{l|c|c|c|c|c|c}
\hline \multirow{2}{*}{\multicolumn{1}{c|}{ N management }} & \multicolumn{2}{|c|}{ PI stage } & \multicolumn{2}{c|}{ FI stage } & \multicolumn{2}{c}{ Dough stage } \\
\cline { 2 - 7 } & SPAD & $\begin{array}{c}\text { N content } \\
(\%)\end{array}$ & SPAD & $\begin{array}{c}\text { content } \\
(\%)\end{array}$ & SPAD & $\begin{array}{c}\text { N content } \\
(\%)\end{array}$ \\
\hline Control & 33.5 & 2.82 & 34.9 & 1.64 & 34.0 & 1.64 \\
40kg N/ha & 35.2 & 3.05 & 37.8 & 1.75 & 36.4 & 1.75 \\
80kg N/ha & 35.7 & 3.33 & 39.5 & 1.88 & 37.4 & 1.88 \\
120kg N/ha + Basa1 & 36.8 & 3.47 & 39.4 & 2.00 & 39.3 & 2.00 \\
l20kg N/ha -Basal & 37.0 & 3.51 & 41.1 & 2.12 & 41.1 & 2.12 \\
l60kg N/ha + Basal & 39.5 & 3.83 & 42.6 & 2.20 & 42.0 & 2.20 \\
160kg N/ha-Basal & 39.2 & 3.82 & 40.9 & 1.99 & 42.9 & 1.99 \\
SPAD35+ Basal & 36.6 & 3.60 & 41.7 & 2.07 & 38.4 & 2.07 \\
SPAD35-Basal & 36.0 & 3.49 & 38.8 & 1.89 & 39.1 & 1.89 \\
USG(80kg N/ha) & 40.0 & 3.97 & 37.7 & 1.79 & 37.0 & 1.79 \\
\hline
\end{tabular}

On the other hand, all the hybrid and inbred varieties showed higher amount of chlorophyll at panicle initiation and flowering stages compared to dough stage in both seasons. Considering the $\mathrm{R}^{2}$ value, the relationship was stronger at panicle initiation and flower initiation stage compared to soft dough stages for all varieties (Fig. 1a and 1b). Mamin (2003) reported a strong, linear and positive relationship between SPAD values and chlorophyll a and b contents.

\section{Relationship between SPAD value and leaf $\mathbf{N}$ content}

Table. 2.1, 2.2 and 2.3 show the relationship between SPAD values and leaf $\mathrm{N}$ content (\%) of different varieties under different $\mathrm{N}$ management at different growth stages in Boro 2002. At critical value SPAD35, Sonarbangla-1 showed about $3.0 \% \mathrm{~N}$ in leaves at $\mathrm{P} 1$ stage, $1.6 \%$ at Fl stage and $1.3 \%$ at dough stage (Table 2.1). BRRI hybrid dhan0l showed 3.2, 1.5 and 1.4\% N, respectively, at similar growth stages (Table 2.2). BRRI dhan29 showed 3.4, 1.6, and 1.3\% N, respectively, at similar growth stages (Table 2.3). The results indicated that all the varieties showed optimum level $(>3.0 \% \mathrm{~N})$ at P1 stage but deficiency level $(<2.0 \% \mathrm{~N})$ at $\mathrm{Fl}$ and dough stages (Dobermann and Fairhurst, 2000). On the other hand, the same variety Sonarbangla-1 showed 2.2, 1.5 and 1.2\% N, respectively, at P1, Fl and dough stage during T. Aman 2002 (Table 3.1). BRRI hybrid dhan0l showed 2.6, 1.35 and $1.15 \% \mathrm{~N}$, respectively, at similar growth stages (Table 3.2). BRRI dhan31 showed 2.1, 1.5, and 1.3\% N, respectively, at similar growth 
Table 2.2. SPAD reading and $N$ content in leaves of Sonarbangla- 1 under different nitrogen management, Boro 2002.

\begin{tabular}{|c|c|c|c|c|c|c|}
\hline \multirow[b]{2}{*}{$\mathrm{N}$ management } & \multicolumn{2}{|c|}{ PI stage } & \multicolumn{2}{|c|}{ FI stage } & \multicolumn{2}{|c|}{ Dough stage } \\
\hline & SPAD & $\begin{array}{c}\text { N content } \\
(\%)\end{array}$ & SPAD & $\begin{array}{c}\mathrm{N} \text { content } \\
(\%)\end{array}$ & SPAD & $\begin{array}{c}\mathrm{N} \text { content } \\
(\%)\end{array}$ \\
\hline Control & 34.6 & 3.12 & 34.4 & 1.43 & 33.2 & 1.30 \\
\hline $40 \mathrm{~kg} \mathrm{~N} / \mathrm{ha}$ & 35.9 & 3.24 & 36.3 & 1.63 & 35.1 & 1.43 \\
\hline $80 \mathrm{~kg}$ N/ha & 36.0 & 3.34 & 37.2 & 1.70 & 36.0 & 1.52 \\
\hline 120kg N/ha + Basal & 36.7 & 3.46 & 38.4 & 1.88 & 37.7 & 1.52 \\
\hline 120kg N/ha -Basal & 38.0 & 3.54 & 38.7 & 1.83 & 39.4 & 1.62 \\
\hline 160kg N/ha + Basal & 39.6 & 4.05 & 40.9 & 1.95 & 41.1 & 1.65 \\
\hline 160kg N/ha-Basal & 39.4 & 4.01 & 41.4 & 1.99 & 41.0 & 1.63 \\
\hline SPAD35+ Basal & 36.8 & 3.54 & 37.2 & 1.68 & 35.9 & 1.43 \\
\hline SPAD35-Basal & 36.3 & 3.41 & 37.7 & 1.72 & 39.0 & 1.59 \\
\hline USG(80kg N/ha) & 40.4 & 4.08 & 39.0 & 1.81 & 36.3 & 1.44 \\
\hline
\end{tabular}

Table 2.3. SPAD reading and 1 content in leaves of BRRI dhan29 under different nitrogen management, Boro 2002.

\begin{tabular}{l|c|c|c|c|c|c}
\hline \multirow{2}{*}{\multicolumn{1}{c|}{ N management }} & \multicolumn{2}{c|}{ PI stage } & \multicolumn{2}{c|}{ FI stage } & \multicolumn{2}{c}{ Dough stage } \\
\cline { 2 - 8 } & SPAD & $\begin{array}{c}\text { N content } \\
(\%)\end{array}$ & SPAD & $\begin{array}{c}\text { content } \\
(\%)\end{array}$ & SPAD & $\begin{array}{c}\text { N content } \\
(\%)\end{array}$ \\
\hline Control & 35.0 & 3.41 & 34.5 & 1.48 & 34.4 & 1.30 \\
$40 \mathrm{~kg} \mathrm{~N} / \mathrm{ha}$ & 35.7 & 3.49 & 34.9 & 1.57 & 35.5 & 1.40 \\
80kg N/ha & 36.9 & 3.56 & 37.3 & 1.81 & 37.2 & 1.46 \\
$120 \mathrm{~kg} \mathrm{~N} / \mathrm{ha}+$ Basa1 & 37.1 & 3.60 & 38.6 & 1.88 & 38.0 & 1.51 \\
l20kg N/ha -Basal & 37.9 & 3.61 & 39.4 & 1.91 & 37.6 & 1.48 \\
l60kg N/ha + Basal & 41.0 & 3.88 & 40.3 & 2.01 & 40.9 & 1.72 \\
160kg N/ha-Basal & 40.2 & 3.79 & 40.8 & 1.99 & 42.7 & 1.78 \\
SPAD35+ Basal & 37.6 & 3.60 & 37.9 & 1.82 & 36.0 & 1.41 \\
SPAD35-Basal & 38.3 & 3.63 & 39.6 & 1.85 & 38.6 & 1.55 \\
USG(80kg N/ha) & 40.9 & 3.88 & 37.6 & 1.68 & 34.7 & 1.31 \\
\hline
\end{tabular}

stages (Table 3.3). It was clear from the results that the $\mathrm{N}$ content in leaves varied in different varieties at different growth stages. Sonarbangla-1 and BRRI hybrid dhan0l showed higher $\mathrm{N}$ content in leaves at all growth stages in Boro compared to T. Aman season. There is a strong relationship between SPAD values and leaf $\mathrm{N}$ concentration, but this relationship varies with crop growth stage and or variety (Turner and Jund, 1994), mostly because of leaf thickness or specific leaf 
weight (Peng et al., 1993). The relationship between leaf $\mathrm{N}$ content and SPAD value indicated that when a variety will show higher SPAD value, it has certainly higher amount of nitrogen.

Table 3.1. SPAD reading and $\mathrm{N}$ content in leaves of Sonarbangla-1 under different nitrogen management, T. Aman 2002.

\begin{tabular}{l|c|c|c|c|c|c}
\hline \multirow{2}{*}{\multicolumn{1}{c|}{ N management }} & \multicolumn{2}{|c|}{ PI stage } & \multicolumn{2}{c|}{ FI stage } & \multicolumn{2}{c}{ Dough stage } \\
\cline { 2 - 8 } & SPAD & $\begin{array}{c}\text { N content } \\
(\%)\end{array}$ & SPAD & $\begin{array}{c}\text { content } \\
(\%)\end{array}$ & SPAD & $\begin{array}{c}\text { N content } \\
(\%)\end{array}$ \\
\hline Control & 35.1 & 2.22 & 34.9 & 1.49 & 33.5 & 1.17 \\
40kg N/ha & 36.2 & 2.61 & 37.8 & 1.70 & 35.4 & 1.22 \\
80kg N/ha & 36.9 & 2.68 & 39.5 & 1.85 & 36.4 & 1.32 \\
120kg N/ha + Basa1 & 37.3 & 2.97 & 39.4 & 1.92 & 37.8 & 1.41 \\
l20kg N/ha -Basal & 38.6 & 3.06 & 41.1 & 2.12 & 39.1 & 1.50 \\
160kg N/ha + Basal & 39.5 & 3.33 & 42.6 & 2.20 & 40.5 & 1.60 \\
160kg N/ha-Basal & 39.7 & 3.42 & 40.9 & 1.99 & 40.6 & 1.63 \\
SPAD35+ Basal & 38.0 & 3.25 & 41.7 & 2.07 & 37.0 & 1.44 \\
SPAD35-Basal & 38.0 & 3.04 & 38.8 & 1.74 & 36.0 & 1.37 \\
USG(80kg N/ha) & 41.0 & 3.62 & 37.7 & 1.79 & 36.5 & 1.38 \\
\hline
\end{tabular}

Table 3.2. SPAD reading and $N$ c ntent in leaves of BRRI hybrid dhan0l under different nitrogen management, T. Aman 2002.

\begin{tabular}{l|c|c|c|c|cc}
\hline \multirow{2}{*}{\multicolumn{1}{c}{ N management }} & \multicolumn{2}{c|}{ PI stage } & \multicolumn{2}{c|}{ FI stage } & \multicolumn{2}{c}{ Dough stage } \\
\cline { 2 - 8 } & SPAD & $\begin{array}{c}\text { N content } \\
(\%)\end{array}$ & SPAD & $\begin{array}{c}\text { N content } \\
(\%)\end{array}$ & SPAD & $\begin{array}{c}\text { N content } \\
(\%)\end{array}$ \\
\hline Control & 35.4 & 2.83 & 34.9 & 1.33 & 34.2 & 1.10 \\
40kg N/ha & 36.4 & 2.90 & 36.3 & 1.53 & 35.1 & 1.19 \\
80kg N/ha & 37.0 & 3.04 & 37.2 & 1.65 & 36.2 & 1.27 \\
120kg N/ha + Basa1 & 37.5 & 3.08 & 38.4 & 1.78 & 37.2 & 1.37 \\
120kg N/ha -Basal & 38.0 & 3.24 & 39.0 & 1.73 & 38.2 & 1.57 \\
160kg N/ha + Basal & 40.1 & 3.56 & 40.9 & 1.90 & 41.6 & 1.65 \\
160kg N/ha-Basal & 39.4 & 3.50 & 41.4 & 1.79 & 42.0 & 1.63 \\
SPAD35+ Basal & 37.4 & 3.12 & 37.5 & 1.58 & 36.4 & 1.33 \\
SPAD35-Basal & 36.3 & 2.78 & 36.7 & 1.47 & 36.6 & 1.29 \\
USG(80kg N/ha) & 40.9 & 3.84 & 40.0 & 1.81 & 36.8 & 1.44 \\
\hline
\end{tabular}


Table 3.3. SPAD reading and $\mathrm{N}$ content in leaves of BRRI dhan 31 under different nitrogen management, T. Aman 2002.

\begin{tabular}{l|c|c|c|c|c|c}
\hline \multirow{2}{*}{\multicolumn{1}{c|}{ N management }} & \multicolumn{3}{c|}{ PI stage } & \multicolumn{2}{c|}{ FI stage } & \multicolumn{2}{c}{ Dough stage } \\
\cline { 2 - 7 } & SPAD & $\begin{array}{c}\text { N content } \\
\%\end{array}$ & SPAD & $\begin{array}{c}\text { N content } \\
\%\end{array}$ & SPAD & $\begin{array}{c}\text { N content } \\
\%\end{array}$ \\
\hline Control & 34.9 & 2.09 & 34.2 & 1.56 & 34.1 & 1.19 \\
40kg N/ha & 36.3 & 2.27 & 36.1 & 1.61 & 34.8 & 1.31 \\
80kg N/ha & 37.3 & 2.35 & 36.0 & 1.66 & 35.4 & 1.31 \\
120kg N/ha + Basa1 & 39.8 & 2.62 & 37.8 & 1.84 & 37.1 & 1.44 \\
l20kg N/ha -Basal & 41.1 & 2.90 & 37.8 & 1.78 & 37.5 & 1.52 \\
160kg N/ha + Basal & 42.7 & 3.00 & 39.8 & 2.05 & 40.8 & 1.68 \\
160kg N/ha-Basal & 42.0 & 2.99 & 40.1 & 2.08 & 40.6 & 1.73 \\
SPAD35+ Basal & 36.2 & 2.38 & 37.9 & 1.91 & 36.8 & 1.48 \\
SPAD35-Basal & 35.9 & 2.38 & 37.9 & 1.83 & 37.0 & 1.46 \\
USG(80kg N/ha) & 39.1 & 2.62 & 39.0 & 1.98 & 36.2 & 1.41 \\
\hline
\end{tabular}

\section{Changing pattern of SPAD and LCC readings}

Figure 3a shows that Sonarbangla- 1 reached critical SPAD value (35) at 27 DAT and at $55 \mathrm{DAT}$ in $\mathrm{T}_{8}$. At that time, the LCC reading was 3.0. On the other hand, Sonarbangla- 1 reached a much lower SPAD value of 30 at 20 DAT and at critical SPAD value in between 55 and 62 DAT in $\mathrm{N}_{8}$. The critical level of LCC reading was found to be 3.0 for Sonarbangla-1 in Boro season. Similarly, BRRI hybrid dhan0l reached critical SPAD value at 27 DAT, in between 55 and 62 DAT and in between 76 and 83 DAT in $\mathrm{N}_{7}$. At that time, the LCC reading was about 3.0. On the other hand, BRRI hybrid dhanl reached a much lower SPAD value at 20 DAT and at critical SPAD (35) in between 55 and 62 DAT and 76 and 83 DAT in $\mathrm{N}_{8}$. The critical value of LCC reading was in between 3.0 and 3.2 for BRRI hybrid dhan0l in Boro season (Fig. 3b).

BRRI dhan29 reached at critical SPAD (35) value at 27 DAT in between 55 and 62 DAT and 76 and 83 DAT in $\mathrm{N}_{7}$. At the time of interception with critical SPAD value, the LCC reading was 3.0 for $\mathrm{N}_{7}$. On the other hand, BRRI dhan29 reached a much lower SPAD value (32) at 20 DAT and at critical SPAD level (35) in between 55 and 62 DAT and 76 and 83 DAT for N8. Therefore, the critical level of LCC reading might be in between 3.0 and 3.2 for BRRI dhan29 (Fig. 3c).

Figure 4a indicates that Sonarbangla-1 reached critical SPAD value (35) only at 55 DAT in $\mathrm{N}_{7}$ where basal $\mathrm{N}$ was applied. At that time, the LCC reading was 3.4. On the other hand, Sonarbangla-1 reached critical SPAD value at 48 DAT in $\mathrm{N}_{8}$ when basal $\mathrm{N}$ was not applied. At that time the LCC reading was 3.4. So, the critical level of LCC reading might be 3.4 for Sonarbangla-1 in T. Aman season. 

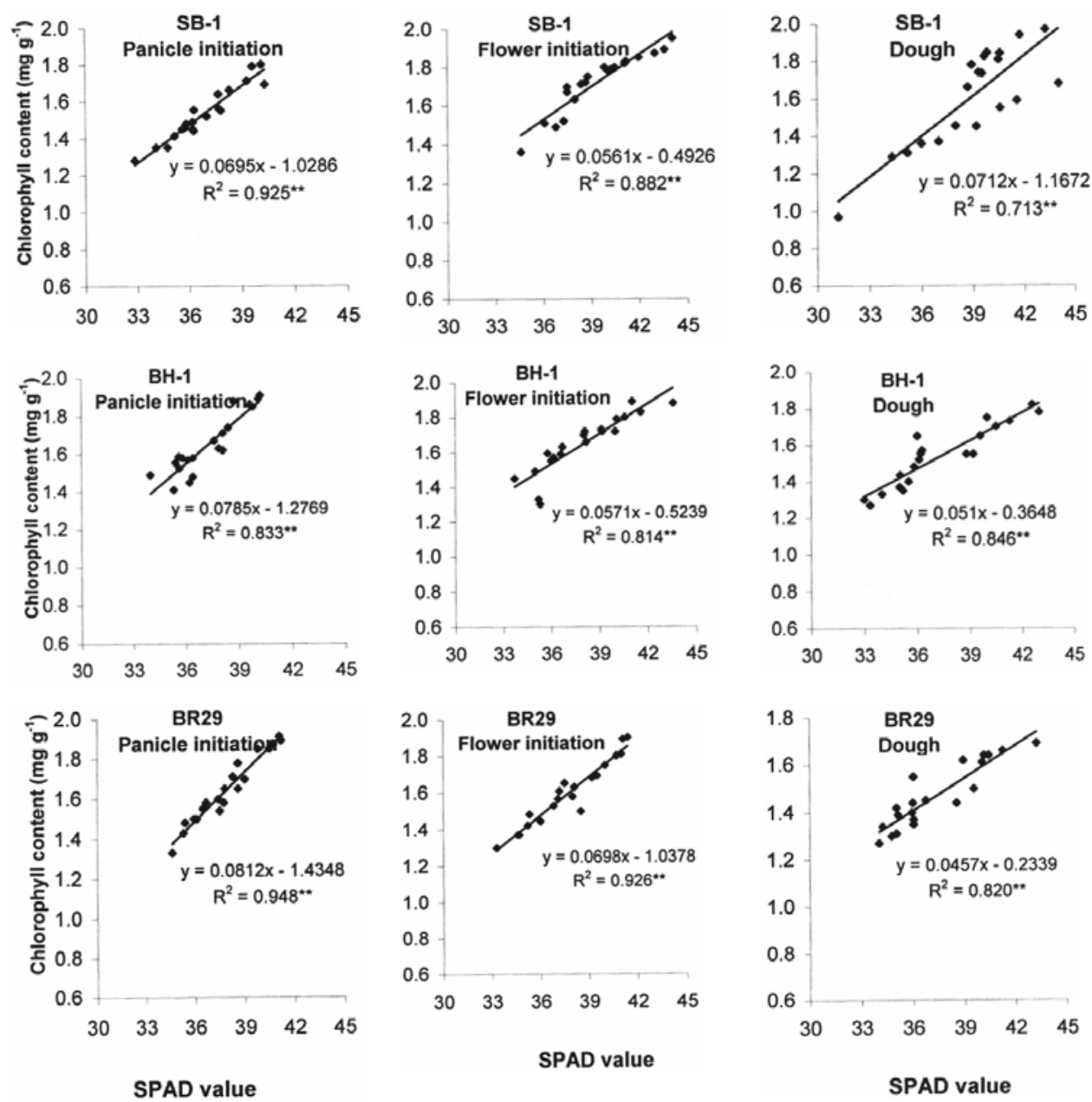

Fig. 1a. Relationship between chlorophyll content in leaves and SPAD values of different varieties at different growth stages in Boro rice. (SB-1= Sonarbangla-1, BH-1=BRRI hybrid dhan01 and BR29= BRRI dhan29).

Fig. 4b shows that BRRI hybrid dhan0l reached critical SPAD value (35) only at 55 DAT in $\mathrm{N}_{7}$ when basal $\mathrm{N}$ was applied. At that time, the LCC reading was 3.4. On the other hand, BRRI hybrid dhan0l reached at critical SPAD level at 48 DAT in $\mathrm{N}_{8}$ when basal $\mathrm{N}$ was not applied. At that time, the LCC reading was 3.4. So, the critical level of LCC reading might be 3.4 for BRRI hybrid dhan0l in T. Aman. BRRI dhan3l reached critical SPAD value (35) only at 55 DAT in $\mathrm{N}_{7}$ when basal $\mathrm{N}$ was applied. At that time, the LCC reading was 3.4. On the other hand, BRRI dhan31 reached at critical level in between 41 and 48 DAT in $\mathrm{N}_{8}$ when basal $\mathrm{N}$ was not applied. At that time the LCC reading was 3.4 (Fig. 4c). So, the critical level of LCC reading might be 3.4 for BRRI dhan3l in T. Aman. 

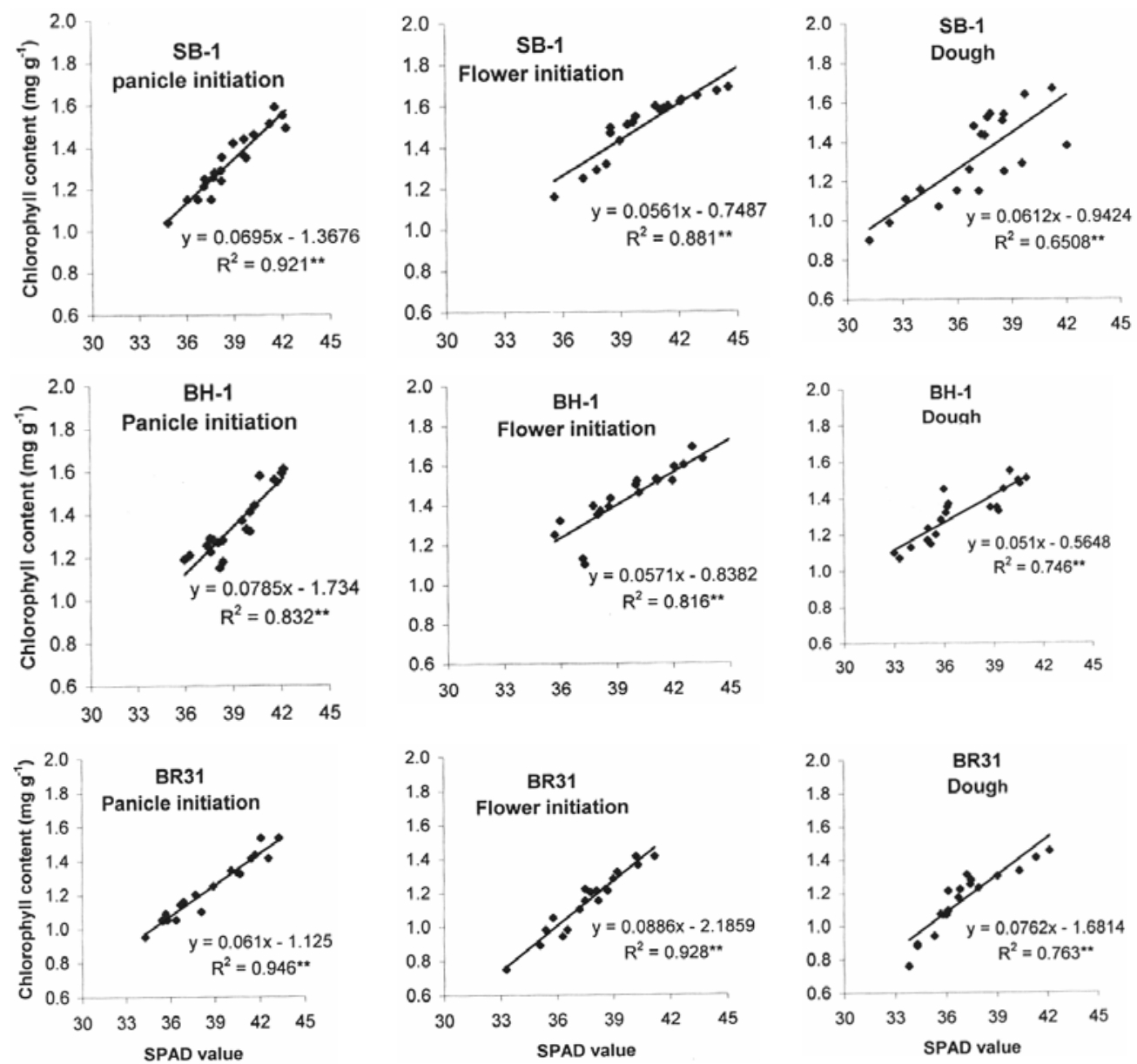

Fig. 1b. Relationship between chlorophyll content in leaves and SPAD values of different varieties at different growth stages in T.Aman rice. (SB-1= Sonarbangla-1, BH-1=BRRI hybrid dhan01 and BR29= BRRI dhan31).

From the above results, it is clear that the critical LCC value for BRRI dhan29 was 3.0 in Boro season and for BRRI dhan31 was 3.4 in T. Aman. This finding is in agreement with that reported by Islam et al. (1998). The hybrid varieties Sonarbangla-1 and BRRI hybrid dhan0l expressed critical LCC reading of 3.0 in Boro season and 3.4 in T. Aman season. Thus, leaf colour is a reliable indicator of $\mathrm{N}$-status in plants, which might vary from season to season and variety to variety. Although leaf colour is a genetic character, little difference in leaf colour was observed with the varieties under study. The critical LCC values of different varieties based on SPAD 35 threshold value have been summarized in Table 1. Critical LCC values need to be adjusted with nearest whole number or 0.5 unit for practical readability. 

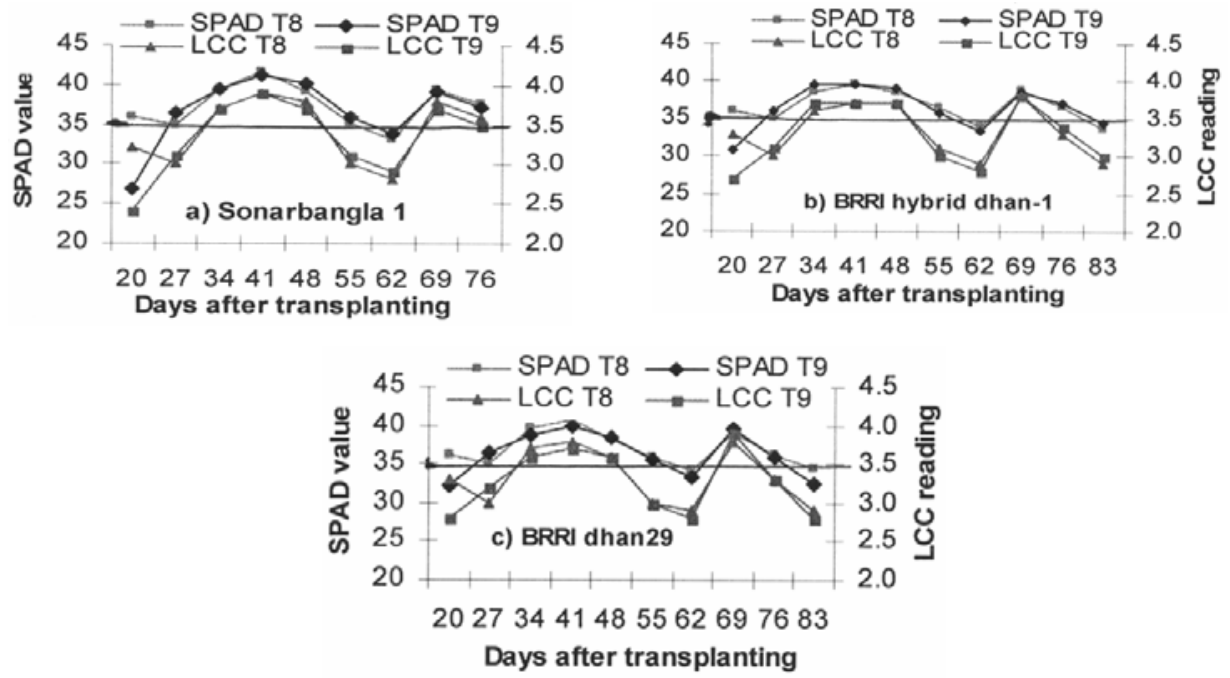

Fig. 2a, b and c, Changing pattern of SPAD and LCC value of 3 variety at different DAT in Boro rice.
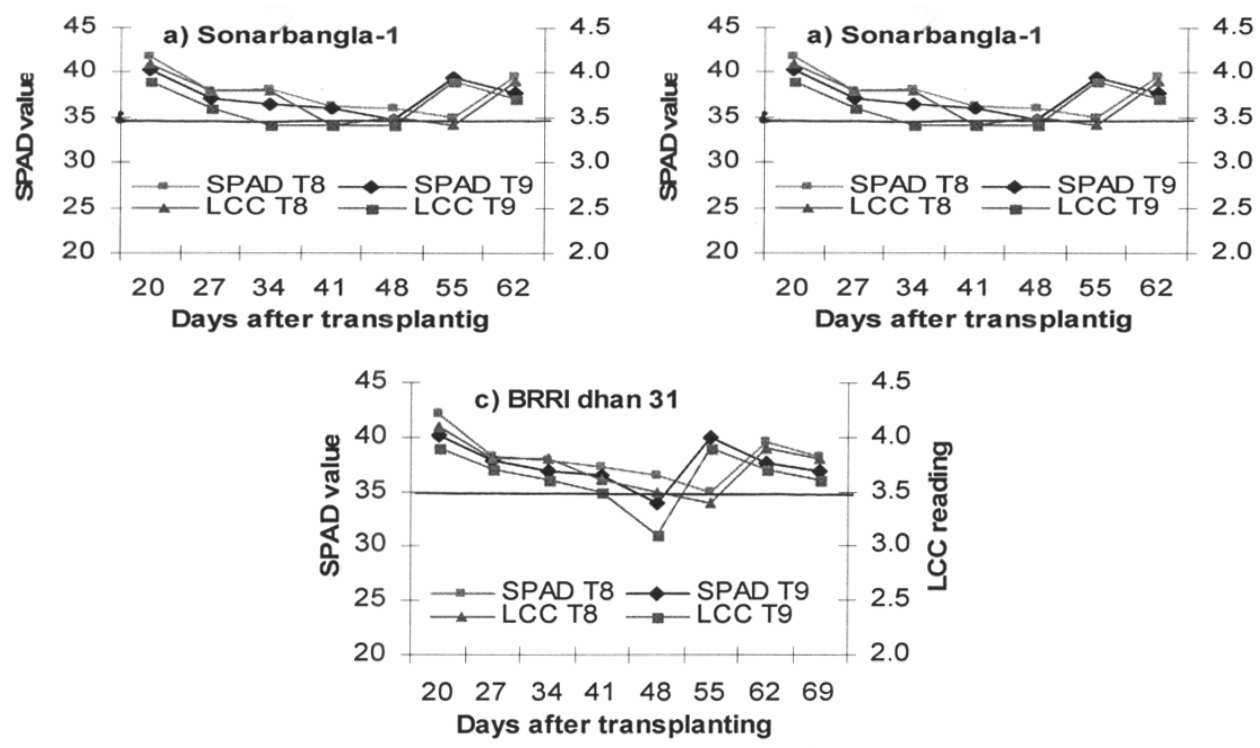

Fig. 3a, b and c. Changing pattern of SPAD and LCC value of 3 varieties at different DAT in T.Aman rice.

\section{Conclusion}

It may be concluded that when rice leaves will show $>35$ SPAD value, it has higher amount of chlorophyll as well as nitrogen. The adjusted critical LCC value is 3.0 for Boro and 3.5 for T. Aman seasons. 


\section{References}

Ali, M.A. 2005. Productivity and resource use efficiency of rice as affected by crop establishment and N management. PhD Dissertation, UPLB, Philippinesi p. 82

Balasubramanian, V., A.C. Morales, R.T. Cruz and S. Abdulrachman. 1999. On farm adaptation of knowledge-intensive nitrogen management technologies for rice systems. Nutr. Cycl. Agroecosyst. 53(1): 59-69.

Page, A.L., 1982. Methods of Soil Analysis. Part I \& II. The Am. Soc. of Agron., Madison, Wisconsin, USA, Agric. 12: 360-366.

Dobermann, A. and T. Fairhurst. 2000. Mineral deficiencies. In: "Rice: Nutrient Disorder and Nutrient Management”. Potash \& Phosphate Institute and Intl. Rice Res. Inst. pp. 41-71.

Hussain, F., K.F. Bronson, Y. Sing, B. Sing and S. Peng. 2000. Use of Chlorophyll Meter Sufficiency Indices for Nitrogen Management of Irrigated Rice in Asia. Agron. J. 92: 875-779.

Islam, M.Sh, M.R. Islam and Z. U. Ahmed. 1998. Evaluation of nitrogen management based on chlorophyll meter (SPAD) value in modern rice varieties under wet and dry seasons. Bangladesh J. Agron. 8(1 \& 2): 37-45.

Mamin, S. I. 2003. Photosynthesis, shoot reserve translocation, lodging and nitrogen use efficienc of modern and traditional varieties of rice. Ph.D Dissertation, BSMRAU, Gazipur p. 272.

Miah, M.A.M. and Z.U. Ahmed. 2002. Comparative efficiency of the chlorophyll meter technique, urea supper granule and prilled urea for hybrid rice in Bangladesh. In: "Hybrid Rice in Bangladesh: Progress and Future Strategies". pp. 43-50. Bangladesh Rice Res. Inst., Publication No. 138.

Mikkelsen, D. S., G. R. Jayaweera and D. E. Rolston. 1995. Nitrogen fertilization practices of lowland rice culture. In: "Nitrogen fertilization and the environment". pp. 171-223.

Peng, S., J.U. Yang, F.V. Carcia, and R.C. Laza. 1998. Physiology based crop management for yield maximization of hybrid rice. In: "Advances in Hybrid Rice Technology”. In: Proc. 3rd Intl. Symp. on Hybrid rice. pp.157-176. Intl. Rice Res. Ins., Los Banos, Philippines.

Peng, S., F. C. Garcia, R. C. Laza, K. G. Cassman. 1993. Adjustment for specific leaf weight improves chlorophyll meters estimation of rice leaf nitrogen concentration. Agron. J. 85: 987-990.

Peng, S., F. V. Garcia, R. C. Laza, A. L. Sanico, R. M Visperas and K. G. Cassman. 1996. Increased N-use efficiency using a chlorophyll meter on high-yielding irrigated rice. Field Crops Res. 47: 243-252.

Turner, F. T. and M. F. Jund. 1994. Assessing the nitrogen requirements of rice crops with a chlorophyll meter method. Aust. J. Exp. Agric. 34: 1001-1005.

Yoshida, S., A.F. Douglas H.C. James and K.A. Gomez. 1976. Determination of chlorophyll in plant tissue. In: Laboratory Manual for Physiological Studies of Rice (3rd edition). p. 43. International Rice Research Institute, Los Banos, Philippines. 